Idun Heir Senstad

\title{
Literary Diversity through Translation: The Role of Independent Cultural Mediators in the Selection of Cuban Literature in Norway
}

\section{Introduction}

This article examines the role of independent cultural mediators-such as translators-in the selection of literary works for translation. It explores how and why they suggest titles to publishers, and by extension how, through their choices, they contribute to literary diversity. Publishers are the final gatekeepers of translation selection since they make the final decision as to whether or not to commission a translation; however, their decisions are always embedded in wider, transnational gatekeeping networks (Franssen and Kuipers 49). Translators and other independent cultural mediators form part of these networks, but they normally play a minor role. For most publishers, agents employed in the publishing industry-such as literary scouts, literary agents and publisher colleagues in other countries-are particularly important sources of relevant titles and advice (Franssen and Kuipers 57; Senstad, "Norwegian Publishers' Views”), and most titles are selected via this central network of publishing professionals.

Translators and other independent cultural mediators form an alternative source of manuscripts or books worthy of translation. Whereas the predominant structures of the international translation field favor translations from central languages and regions, particularly English and the Anglo-American area, translators are often mentioned as important sources of titles from so-called peripheral literatures (Bourdieu 147-148; Franssen and Kuipers 57), i.e., from languages that editors do not read, or geographical areas that are underrepresented in a certain literary field. However, few studies examine translators' impact on selection, and the present article addresses this gap. More specifically, it focuses on the independent cultural mediators who participated in the selection of Cuban literature for translation from Spanish into Norwegian between 1990 and 2014. From a world-system perspective on translation, both Cuba and Norway are peripheries. Spanish is normally considered a semi-peripheral language, accounting for

Idun Heir Senstad, OsloMet - Oslo Metropolitan University

Ә Open Access. (C) 2020 Idun Heir Senstad, published by De Gruyter. (cc) BY-NC-ND This work is licensed under a Creative Commons Attribution-NonCommercial-NoDerivatives 4.0 International License. 
somewhere between $1 \%$ and $3 \%$ of all book translations worldwide (Heilbron 434). Given the large number of Spanish language writers from Spain, Latin America, the US, and the Caribbean, translations of Cuban literature only account for a fraction of this. In Norway, numbers for the years 2011-2016 show that only around $1 \%$ of literary translations -58 of 4579 translated fiction titlesoriginated from Spanish ${ }^{1}$. At the same time, translated literature has a strong position in the Norwegian literary field (a typical trait of peripheral literatures). Official statistics demonstrate that between 29\% and 34\% of books published in Norway between 1991 and 2009² were translations (Kulturstatistikk 2000 101; Kulturstatistikk 2016 154). The publishing statistics do not single out fiction as a category of its own, but sales figures show that the total number of sold copies of translated fiction roughly equaled sold copies of original Norwegian fiction (Kulturstatistikk 2000 106; Kulturstatistikk 2016 157), which is indicative of the strong position of translated literature in the Norwegian market. A diverse representation of different literatures through translation is an ideal for many Norwegian publishers (Senstad, "Norwegian Publishers' Views"); nevertheless, English dominated as a source language from 1991 to 2014, accounting for between $60 \%$ and $73 \%$ of all translated books (Kulturstatistikk 2000 103; Kulturstatistikk 2016 155). By paying close attention to the selection of literature from one periphery, Cuba, in another, Norway, this article highlights how invested cultural mediators can make essential contributions to literary diversity.

Following Roig-Sanz and Meylaerts, a cultural mediator is "a cultural actor active across linguistic, cultural and geographical borders, occupying strategic positions within large networks and being the carrier of cultural transfer" (3). According to this definition, publishers, literary scouts and literary agents may also be cultural mediators. The present study focuses on agents working largely outside the central networks of publishing professionals. I therefore suggest the term independent cultural mediator and use this throughout. Independent cultural mediators are translators or other agents who advocate for and are personally invested in the translation of particular titles and/or literature from particular geographical areas; these works are often originally written in languages that are not common as source languages for literary translation in the given culture. These works would not normally gain publishers' attention through the typical channels.

\footnotetext{
1 Numbers from Den norske Bokdatabasen. Between 2011 and 2016, 5409 translated titles (for adults and children) were published, but only 4579 titles have information on source language in the database. Nummedal, Mona. "RE: Opplysninger til forskningsprosjekt." Received by Idun Heir Senstad, 29 Nov. 2018.

2 The data source changed in 2010, and numbers from this year onward are therefore not directly comparable to preceding years.
} 
Independent cultural mediators are often freelancers and are not formally employed in the publishing sector, even though they are part of it. The rules of the transnational translation market are not irrelevant to the independent cultural mediators, since publishers are the ones who make the final decisions on which titles to publish. However, these agents tend to act largely independently of the overarching structures of the international translation market. Their agency is instead enacted through alternative networks and is often manifested in a multiple mediatorship (Schwartz) through which various independent cultural mediators influence the selection process.

In this article, I study the selection processes surrounding nine Cuban fictional works published in Norwegian between 1990 and 2014. Through dynamic searches in Norwegian online library catalogues, reviews of different Norwegian publishers' websites, and interviews with Norwegian translators and publishers, I uncovered a total of 28 Cuban fictional works published in Norwegian during this period. Independent cultural mediators (the translators of the works, or in one case an independent series editor) suggested nine of these works, which form the basis for the study in this article. The nine works were translated by four different translators-Kjell Risvik, Tove Bakke, Kari Näumann, and Hege Hammer-and include novels by the contemporary Cuban writers Wendy Guerra, Pedro Juan Gutiérrez, and Leonardo Padura, as well as canonized classics of $20^{\text {th }}$ century Cuban literature, namely poems and short stories by Virgilio Piñera, poems by Dulce María Loynaz and Ángel Escobar, and finally, José Lezama Lima’s novel Paradiso. The main material for this study consists of interviews with the four translators as well as the prefaces and epilogues (where these exist) printed in the Norwegian translations. This material enabled me to study different contextual voices (Alvstad et al.)-the oral and written manifestations of different agents' involvement in the selection processes-surrounding the Norwegian translations of the nine Cuban works.

There are at least four reasons why the chosen material-the selection of nine Cuban fictional works in Norway-and the period-1990 to 2014-are particularly fitting for a study of the role and impact of independent cultural mediators. Firstly, the Norwegian book market is small, automatically limited by the fact that Norway has only approximately five million inhabitants. This makes it feasible to include all Cuban fictional works introduced by independent cultural mediators throughout a relatively long period of 25 years. Secondly, a small "corpus" of nine translated books allows me to combine micro-, meso- and macrolevel approaches to selection. In the first part of the analysis, I study single actors involved in the translation and selection processes (micro-level), and I address the role that state cultural policies played in the work of these individuals (mesolevel). In the second part, I present the cultural mediators' choices in light of the 
regional and international consecration of the nine Cuban works (macro-level), and I relate this to a study of Spanish Caribbean literature in Sweden for the same period (Lindqvist, "Bibliomigrationsmönster").

The year 1990 is a natural starting point for this study from both a Cuban and a Norwegian perspective. The third reason why the material in this article constitutes a fruitful case is that the 1990s brought important changes to the international circulation of Cuban literature and, by extension, brought a considerable increase in Cuban literature published in Norway. The fourth reason is that a successful state funding program for translation in Norway, namely, the purchasing scheme for translated literature, was established in 1990. Together, these factors set the stage for a dynamic analysis that can demonstrate ways in which independent cultural mediators' activities and choices are entangled in multi-level contexts.

Through focusing on the independent cultural mediators who introduced Cuban literature to Norwegian readers between 1990 and 2014, the present study asks: Who are the independent cultural mediators? What motivated them to suggest particular titles to the publishing houses? What kinds of books did they suggest, and what was the impact of their choices on the general availability of different literatures in a given book market? What was the role of state funding in the work of these independent cultural mediators? In what ways do their choices relate to literary consecration processes?

\section{Background}

\section{Cuban literature and its international circulation since the 1990s}

Prior to 1990, the only Cuban literary works published in Norwegian translation were four novels by Alejo Carpentier (published in Norwegian in 1958, 1965, 1976 and 1978), one novel by Luis Rogelio Nogueras (1984), a poetry anthology (1973), and a few more poems and short stories in anthologies on Latin American literature (Izquierdo). The period from the 1990s onwards saw an upsurge in Cuban literature in Norway, with 28 titles published between 1990 and 2014. This upsurge should be understood in the light of more general developments in the international circulation of Cuban literature and other cultural expressions from the 1990s, often referred to as a "Cuban boom" (Whitfield 10-15; see also Senstad, "Bokomslag" 175-177; "The Making of a Bestseller-inTranslation" 66-68). Editors and other cultural producers in Europe, the United 
States, and elsewhere took an interest in Cuba when the socialist island opened up to more contact with capitalist countries due to changing realities after the disintegration of the Soviet Union and the fall of communism in Europe. Without Soviet trade, Cuba entered a severe economic crisis, affecting all sectors of society. The state-run literary industry faced wide-ranging problems with technical equipment and paper supplies, and it was obliged to keep book production to an absolute minimum (Kumaraswami and Kapcia 132-135). In 1993, Cuban authorities issued a decree that allowed writers, for the first time since the 1959 socialist revolution, to sign contracts with publishers abroad without state involvement. For Cuban writers, this meant enhanced possibilities of being published in times of crisis, and it even carried prospects of economic gain (nearly inexistent in a state-run Cuban literary industry devoid of any market concerns) and censorship circumvention. As the world followed the Cuban developments and waited for the socialist regime to either collapse or survive, foreign editors started looking for literary talent on the island. Travels to Cuba became easier-opening to tourism was one of the Cuban authorities' main strategies to cope with the economic crisis-and many editors and other cultural producers (filmmakers, documentarians, and journalists, etc.) travelled there. Pedro Juan Gutiérrez's Trilogia sucia de La Habana-one of the nine works studied in this article-is one of the most successful literary examples from this period. Gutiérrez's first contact with the international publishing industry was a visiting French publisher who later passed the manuscript to a Spanish agent (Gutiérrez, Diálogo 122-123). The prestigious Spanish publishing house Anagrama published the book in 1998, and to date the book has been translated into 21 languages (Gutiérrez, Todo).

\section{State funding for literary translation in Cuba and Norway}

State funding programs in source or target cultures guide translation flows, and they may be of particular importance for the circulation of peripheral literatures beyond national borders (Heilbron and Sapiro 185). Various analyses demonstrate how translations from peripheral languages such as Hebrew and Dutch depended largely on translation subsidies and promotional activities from state institutions in the source culture (Hacohen; Heilbron and Sapiro; van Es and Heilbron). In the receiving culture, states can, for example, "support translation in order to maintain a level of quality that cannot be sustained by their national market (like in France and the Netherlands)" (Heilbron and Sapiro 184-185).

The availability of state funding is one of the factors that influence the decision-making processes of Norwegian editors when they select literary titles for 
translation (Senstad, “Norwegian Publishers' Views”). Throughout the period in focus (1990-2014), there was no source culture funding available from Cuba, and the state-run Cuban literary industry did not have any coherent strategy for promoting Cuban literature internationally. The Agencia Literaria Latinoamericana (ALL), a governmental rights agency established in 1986, was the only entity in Cuba legally in charge of promoting and selling Cuban literature abroad; however, it is illustrative that the agency did not play any important part in the Norwegian selection of the nine works under scrutiny. The poor economy as well as what Kumaraswami and Kapcia describe as a "cclash of cultures' between market-driven global publishing systems and the subsidized Cuban system” (166) contributed to the inefficiency of the state agency. Many Cuban writers refuse to be represented by the ALL. For example, Wendy Guerra, one of the writers in the present study, is represented by the Spanish Antonia Kerrigan Literary Agencyquite a paradox, since the Norwegian selection of the work happened through the translator rather than the agency.

From the Norwegian (receiving) side, the state provides important funding through the Purchasing Schemes for Literature, or Innkjøpsordningene for litteratur in Norwegian. Managed by the Arts Council Norway, the purchasing schemes are widely regarded as a cornerstone of Norwegian literary policy and an important constituting actor in the Norwegian literary field. While the scheme for literature originally written in Norwegian dates back to 1965 , the scheme for translated literature was established in 1990. This coincides with the start of the period studied in the present article, meaning that the possibility of receiving funding through the scheme was a potential influencing factor in the selection process of the nine Cuban works in question. Through the scheme, the Arts Council Norway purchases 500 copies of selected translated titles to be distributed to Norwegian libraries. In an international context, this funding model is unique in that it explicitly emphasizes literary circulation and reading, making high quality literature available at no cost for library users nationwide. It benefits libraries (which are provided with "free" books), publishers (through improved sales), and translators (since 1995, the funding has included extra payments for translators as a means to improve their economic standing). The funding is intended to contribute to translations into Norwegian from as many languages as possible; in other words, it is intended to contribute to diversity in the Norwegian literary landscape. The funding was initially limited to 50 translated titles yearly. This number increased throughout the 2000s, and in 2014, the Arts Council purchased 120 titles (Årsmelding 2014). The publisher must apply for funding prior to the publication of the translation, but after agreeing on a binding contract with the translator, as a means to make sure the book will be translated and published independently of the outcome of the funding application. A 
considerable number of applications for the scheme are refused-this happened to around half of the applications in 2012, 2013, and 2014 (Arsmelding 2014; Årsmelding 2013).

\section{Theoretical framework}

This article takes an agent-oriented approach to the study of literary exchanges between peripheries. The independent cultural mediators in focus are agents who actively suggest or advocate particular titles or writers, thereby aiming to influence publishers' decisions regarding which translations to publish-in other words, they act in the social world to bring about change. In doing so, they enact agency. Agency is here understood as the "willingness and ability to act" (Kinnunen and Koskinen 6). Whereas willingness implies a "particular internal state and disposition" (6), ability relates to power and choice. This means that agency can be closely connected to professional and social status (7). Publishers will normally only take suggestions from translators or other individuals that they know and trust. A certain degree of symbolic capital in the Norwegian literary field thus seems to be a necessary precondition for cultural mediators' agency in translation selection processes.

As elaborated upon in the introduction, in this study I apply the term independent cultural mediator. Roig-Sanz and Meylaerts argue that, in the sociologically-oriented field of translation studies, the preference to study translators may be conceptually problematic because the agents involved in intercultural mediation often assume various roles (such as translator, writer, art and literary critic, journalist, etc.) $(6,8)$. They furthermore suggest that cultural mediators involved in periphery-to-periphery exchanges are either "smugglers" or "customs officers." While the customs officer "hinders exchange” (3), smugglers are agents who "promote exchanges and often create their own norms, circuits, channels and forms" (14). A thorough understanding of mediation processes should take into account this variety. The concept of independent cultural mediator as applied in the present study allows for the study of mediators other than translators, while at the same time highlighting that these mediators work largely independently of the established transnational networks of the publishing industry.

The object of study in the present article-the selection processes leading to the Norwegian translation of Cuban literary works-furthermore requires an emphasis on networks. Cultural mediators operate in the social world, and multiple agents influence the final selection of works. Schwartz employs the term 
multiple mediatorship to study "the combined contributions of several mediators as members of interconnected networks" (527) at work in literary exchanges between semi-peripheries (in Schwartz's article, Italy and Sweden). The term is a modification of multiple translatorship (Jansen and Wegener), which focuses on how different actors, apart from the translator, are involved in and influence translations; the term is employed in the study of agents such as copy editors (Solum, "The Tacit Influence") or literary critics (Solum, “Translators, Editors, Publishers, and Critics"). The focus of the present article is on the processes leading up to the commissioning of a translation, and it ends when the textual translation starts, so to speak. Multiple mediatorship helps emphasize this. I also find the term particularly useful because it explicitly allows for the inclusion of mediators who are not translators, and in this way, it fits neatly with the notion of the cultural mediator (as elaborated above).

Finally, this article draws on macro-oriented approaches to literary circulation and consecration. Of particular relevance to the present study is a theoretical framework developed by Lindqvist to understand, precisely, the "bibliomigrancy patterns of Caribbean and Scandinavian literature during the period 1990-2010” (“The Scandinavian Literary Translation Field” 174). This framework builds on Bourdieu and Casanova, and it proposes two central hypotheses: (1) that "double consecration"-first in a regional context, and then in the Anglo-American culture-is a necessary condition for translation between peripheries (Lindqvist, "Bibliomigrationsmönster”, "Dubbel konsekration"); and (2) that Sweden functions as the center of a peripheral, autonomous Scandinavian subfield within the global translation field (Lindqvist, "The Scandinavian"). Following Lindqvist, a precondition for the Norwegian translation of Cuban works would be a "triple" consecration-first in the Hispanic world, then in the Anglo-American area through translation into English, and finally by translation into Swedish and further consecration by agents and institutions in the Swedish field ("The Scandinavian Literary Translation Field" 185). In my analysis, I test this idea on the material of the present study.

\section{Materials and methods}

\section{Nine translations}

Table 1 presents the details of the Cuban works that entered the Norwegian literary system via independent cultural mediators between 1990 and 2014. Apart from these nine books, 19 additional translations of Cuban fictional works were 
Table 1: Norwegian Translations of Cuban Literary Works Selected by Independent Cultural Mediators, 1990-2014.

\begin{tabular}{|c|c|c|c|c|c|}
\hline No. & $\begin{array}{l}\text { Norwegian title } \\
\text { (year, publisher) }\end{array}$ & $\begin{array}{l}\text { Genre, } \\
\text { Source } \\
\text { language }\end{array}$ & Author & Translator & Original title (year) \\
\hline 1 & $\begin{array}{l}\text { Svart vin } \\
\text { (Cappelen, 1999) }\end{array}$ & $\begin{array}{l}\text { Poetry, } \\
\text { Spanish }\end{array}$ & $\begin{array}{l}\text { Dulce María } \\
\text { Loynaz } \\
(1902-1997)\end{array}$ & $\begin{array}{l}\text { Tove } \\
\text { Bakke } \\
\text { (b. 1954) }\end{array}$ & $\begin{array}{l}\text { Selected poems from } \\
\text { Versos (1950), Juegos de } \\
\text { agua (1951), Poemas sin } \\
\text { nombre (1953) and } \\
\text { Bestiarium (1991) }\end{array}$ \\
\hline 2 & $\begin{array}{l}\text { To cubanske: } \\
\text { Virgilio Piñera og } \\
\text { Ángel Escobar i utval } \\
\text { (Samlaget, 2001) }\end{array}$ & $\begin{array}{l}\text { Poetry, } \\
\text { Spanish }\end{array}$ & $\begin{array}{l}\text { Virgilio Piñera } \\
(1912-1979) \\
\text { and Ángel } \\
\text { Escobar } \\
(1957-1997)\end{array}$ & $\begin{array}{l}\text { Tove } \\
\text { Bakke }\end{array}$ & $\begin{array}{l}\text { Selected poems from } \\
\text { Virgilio Piñera: } \\
\text { La isla en peso } \\
\text { (1943/1998) } \\
\text { Ángel Escobar: } \\
\text { Abuso de confianza } \\
\text { (1992), Cuando salí de La } \\
\text { Habana (1996/1997), El } \\
\text { examen no ha terminado } \\
\text { (1997/1999), La sombra } \\
\text { del decir (1997) }\end{array}$ \\
\hline 3 & $\begin{array}{l}\text { Paradiso } \\
\text { (Pax, 2002) }\end{array}$ & $\begin{array}{l}\text { Novel, } \\
\text { Spanish }\end{array}$ & $\begin{array}{l}\text { José Lezama } \\
\text { Lima } \\
(1910-1976)\end{array}$ & $\begin{array}{l}\text { Kjell } \\
\text { Risvik } \\
\text { (b. 1941) }\end{array}$ & Paradiso (1966) \\
\hline 4 & $\begin{array}{l}\text { Kaldt fortalt } \\
\text { (Samlaget, 2004) }\end{array}$ & $\begin{array}{l}\text { Short } \\
\text { stories, } \\
\text { Spanish }\end{array}$ & Virgilio Piñera & $\begin{array}{l}\text { Tove } \\
\text { Bakke }\end{array}$ & $\begin{array}{l}\text { Selected short stories } \\
\text { from Cuentos fríos (1956) }\end{array}$ \\
\hline 5 & $\begin{array}{l}\text { Den skitne Havanna- } \\
\text { trilogien (Gyldendal, } \\
\text { 2005) }\end{array}$ & $\begin{array}{l}\text { Novel, } \\
\text { Spanish }\end{array}$ & $\begin{array}{l}\text { Pedro Juan } \\
\text { Gutiérrez (b. } \\
\text { 1950) }\end{array}$ & $\begin{array}{l}\text { Hege } \\
\text { Hammer } \\
\text { (b. 1966) }\end{array}$ & $\begin{array}{l}\text { Trilogía sucia de La } \\
\text { Habana (1998) }\end{array}$ \\
\hline 6 & $\begin{array}{l}\text { Alle drar sin vei } \\
\text { (Bokvennen, 2011) }\end{array}$ & $\begin{array}{l}\text { Novel, } \\
\text { Spanish }\end{array}$ & $\begin{array}{l}\text { Wendy Guerra } \\
\text { (b. 1970) }\end{array}$ & $\begin{array}{l}\text { Kari } \\
\text { Näumann } \\
\text { (b. 1928) }\end{array}$ & Todos se van (2006) \\
\hline 7 & $\begin{array}{l}\text { Jeg var aldri } \\
\text { førstedame } \\
\text { (Bokvennen, 2012) }\end{array}$ & $\begin{array}{l}\text { Novel, } \\
\text { Spanish }\end{array}$ & Wendy Guerra & $\begin{array}{l}\text { Kari } \\
\text { Näumann }\end{array}$ & $\begin{array}{l}\text { Nunca fui primera dama } \\
\text { (2008) }\end{array}$ \\
\hline 8 & $\begin{array}{l}\text { Vinter i Havana } \\
\text { (Bokvennen, 2012) }\end{array}$ & $\begin{array}{l}\text { Novel, } \\
\text { Spanish }\end{array}$ & $\begin{array}{l}\text { Leonardo Padura } \\
\text { (b. 1955) }\end{array}$ & $\begin{array}{l}\text { Kari } \\
\text { Näumann }\end{array}$ & $\begin{array}{l}\text { Pasado perfecto } \\
(1991 / 2000)\end{array}$ \\
\hline 9 & $\begin{array}{l}\text { Storm i Havana } \\
\text { (Bokvennen, 2014) }\end{array}$ & $\begin{array}{l}\text { Novel, } \\
\text { Spanish }\end{array}$ & $\begin{array}{l}\text { Leonardo } \\
\text { Padura }\end{array}$ & $\begin{array}{l}\text { Kari } \\
\text { Näumann }\end{array}$ & $\begin{array}{l}\text { Vientos de cuaresma } \\
(1994 / 2001)\end{array}$ \\
\hline
\end{tabular}


published in the same period. Most of these remaining works were originally written in English by Cuban-American writers ${ }^{3}$, and gained the attention of Norwegian publishers through networks of publishing professionals (literary scouts, literary agents and editors). These 19 works are therefore discussed in a separate article (Senstad, “Norwegian Publishers’ Views”).

\section{Interviews with translators, prefaces, and epilogues}

Interviews with the four translators, Bakke, Hammer, Näumann (qualitative indepth interviews) and Risvik (brief email interview), comprise the main material for the analysis in this article, combined with readings of the preface and epilogue in the translated books. These two categories of data, interviews and prefaces/epilogues, complement each other in that they represent researchgenerated and naturally occurring data, respectively.

Six of the nine translations are accompanied by a preface or epilogue written by the translator (for Tove Bakke's translations of Dulce María Loynaz, Virgilio Piñera and Ángel Escobar) or by other central mediators (the literary critic and translator Kjell Olaf Jensen for Kjell Risvik’s Lezama Lima translation, and literary scholar Hans Jacob Ohldieck for Kari Näumann's translations of Wendy Guerra). The prefaces/epilogues present and contextualize the authors and works for Norwegian readers, and they include information related to the selection of the works. Prefaces and epilogues are valuable material for translation research (Buendia; Dimitriu; Tahir-Gürcaglar), however they are not common in contemporary Scandinavian literary translations. The inclusion of prefaces/epilogues for the Cuban works adds symbolic value to the translations, and the fact that they were written by agents central to the selection of the works is important because it makes these mediators' agency textually manifest.

Whereas the prefaces and epilogues were produced at the time of translation, interviews conducted various years later are necessarily based on the translators' recollections of events. There are obvious reasons why interviews can be an unstable source of factual information-memories might be blurred and shaped by the time that has passed since the translation took place. Interviewees may have agendas that are unknown to the researcher, and each

3 Fourteen of the 19 titles were written by Cuban-Americans and translated from English; five were written by writers who migrated from Cuba and were translated from Spanish. 
interviewee represents only one of the multiple agents possibly involved in the selection of a particular translation. Yet I consider that interviews with translators, such as the ones conducted for the present study, provide valuable data to the selection process. In this article, I therefore choose to give the stage to the interviewed translators and to trust their accounts. Still, whenever possible, I corroborated the translators' information with data from interviews with eight publishing editors; these interviews were conducted in 2017 and analyzed in Senstad (“Norwegian Publishers' Views”).

\section{Results and discussion}

Here, I will present the selection processes that led to the Norwegian translation and publication of the nine Cuban works in question. I will then sum up these observations and subsequently present a brief analysis of the consecration processes pertaining to the nine works.

\section{Jensen and Risvik introduce Lezama Lima}

José Lezama Lima's major work, Paradiso (1966), was published in Norwegian by the small independent publisher Pax in 2002. The driving force behind this translation was Kjell Olaf Jensen (1946-2016), a respected literary critic and translator (from French and German, not Spanish), who was also a trusted adviser at Pax. Paradiso was published in the relatively short-lived series Pax Sargasso, which, according to the translated book's dust jacket, focused on "modern classics from the third world" (my trans.). Jensen edited the series. In the epilogue, he writes:

I read Paradiso in French many years ago, in a brilliant translation by Didier Coste with support from Lezama Lima's apprentice Severo Sarduy [. . . ]. Kjell Risvik has now [. . .] substantiated what has been my dream ever since I discovered José Lezama Lima as a young man in France, but that I did not dare to hope would be possible: to see this swarming world rendered in Norwegian. For that, he deserves at least my heartfelt gratitude (Jensen 558, my trans.).

It is clear that Paradiso was important to Jensen, and he was personally invested in a Norwegian translation of the work. The French translation (already published in 1971) allowed him access to a work he could not read in its original language, and thus laid the grounds for the future mediation of Lezama in Norway. 
Among the nine works under scrutiny in the present study, the Lezama translation is the only one for which rights were acquired from the aforementioned Cuban state literary agency, the ALL. Unfortunately, potential documentation of this contact was lost from Pax' archives in $2011^{4}$. However, the sum of available information about this translation indicates that the rights arrangements were a formality and that the ALL did not play any significant role in the Norwegian selection of Paradiso. From the Norwegian side, the novel was purchased by the Arts Council Norway (in other words, it received funding through the purchasing scheme for translated literature).

Pax chose to commission the translation of Paradiso from Kjell Risvik (b. 1941), one of Norway's most renowned and experienced translators. Risvik has translated widely from Spanish, but also from Portuguese, Catalan, Italian, French, German, English, and Hebrew (Lomheim)-often together with his wife, translator Kari Risvik. Separately or together, they have received important Norwegian literary prizes, such as the Norwegian Association of Literary Translators' Bastian Prize in 1975, the Norwegian Ministry of Culture's prize for literary translation in 1985, and The Brage Prize Honorary Award in 2006. By 2001, the couple reported having translated around 400 titles ("Med andre ord"), including major works by Gabriel García Márquez, Jorge Luis Borges, Mario Vargas Llosa, and other writers from the so-called Latin American boom. Kjell Risvik reports that he tried to initiate translations of central Cuban writers such as Guillermo Cabrera Infante, Heberto Padilla, Severo Sarduy, and Reinaldo Arenas $^{5}$, but none of these writers had been translated into Norwegian at the time this article was written. This demonstrates how publishers are the final gatekeepers of selection-even suggestions from highly respected translators and literary specialists might not be taken into account.

\section{The agency of Tove Bakke. Loynaz, Piñera and Escobar}

Translator Tove Bakke (b. 1954) stands out as a particularly active and enthusiastic mediator of Cuban literature in Norway. Her translation of a selection of Dulce María Loynaz's poetry was published in 1999 by Cappelen, a traditional publishing house that was Norway's third largest at the time ("Cappelen Damms historie”). Bakke was still in her early translation career. "One of her

4 Nordseth, Linn Kristin. “SV: Arkivspørsmål.” Received by Idun Heir Senstad, 14 Aug. 2018. 5 Risvik, Kjell. “SV: Oversettelser fra Cuba.” Received by Idun Heir Senstad, 29 July 2018. 
collections incidentally ended up on my table without me having any particular interest in either Cuba or Cuban poetry," Bakke wrote in the translation's epilogue (85, my trans.). In the interview, she added that this collection was actually a Spanish-English bilingual edition, which Sigurd Allern-a friend and a known Norwegian politician and academic who did not read or speak Spanish-had picked up while traveling in $\mathrm{Cuba}^{6}$. Bakke wrote, "The poems were written on the other side of the world, and mostly before my time, but I was immediately taken by them" (85, my trans.). She was already involved in another poetry translation for Cappelen and suggested to them that she could translate selected poems by Loynaz instead. The publisher agreed.

Bakke later travelled to Cuba on numerous occasions, often to attend the yearly Havana International Book Fair, which is organized by the Cuban state and is relatively disconnected from the international publishing industry. Her first trip was in 1999, at a time characterized by a renewed interest in Cuban literature (the "Cuban boom"), and the island attracted editors and cultural producers from all over the world who wanted to discover literary and artistic talent. Bakke originally wanted to create a varied collection of Cuban contemporary poetry, modeled upon an Austrian-Cuban bilingual volume from 1998 (Bakke 141). In Cuba, Bakke sought advice from "all the book people” (141, my trans.) she met and finally decided on two (not contemporary) poets: Ángel Escobar (1957-1997) and Virgilio Piñera (1912-1979). Piñera became particularly important to the translator. The now well-known Cuban poet and writer was marginalized during his life because of his homosexuality and critical attitudes towards the development of the Cuban revolutionary project. In Cuba, Bakke developed close relationships with important figures who formed part of both Escobar and Piñera's social circles. These experiences resulted in the translation of selected poems in the collection To cubanske: Virgilio Piñera og Ángel Escobar $i$ utval (Samlaget, 2001). Later she translated a selection of Virgilio Piñera's short stories, entitled Kaldt fortalt in Norwegian (Samlaget, 2004). Both translations are accompanied by Bakke's personalized essays-an epilogue in To cubanske and a preface in Kaldt fortalt-where she presents the authors and her own work with the selection and translation. It is telling of Bakke's enthusiasm and involvement that she personally negotiated the translation rights directly with Piñera's heirs in Cuba. In subsequent travels to the island, she brought the royalties-in cash-that accrued to the heirs of both Piñera and Dulce María Loynaz.

6 Unless otherwise stated, the source of information in this section is Bakke, Tove. Personal interview. 24 Feb. 2016. 
Bakke translated her first book in 1977. She translates widely from mainly Spanish and French (Lauritsen), and is a member of the Norwegian Association of Literary Translators. In 2003 she was awarded the association's annual Bastian Prize, and in 2008 she received Samlagetprisen, the annual prize awarded by the publisher Samlaget. Bakke writes and translates into Nynorsk, one of the two official written variants of Norwegian, which is presumed to be employed by $10-15 \%$ of the population (Vikør and Jahr). Samlaget is a small publisher and the only one that exclusively publishes books in Nynorsk. Other Norwegian publishers usually prefer translations into Bokmål, the more common written variant of Norwegian, but they sometimes accept poetry translations into Nynorsk. Nynorsk is often regarded as more "poetic" than Bokmål, but another important reason why many publishers accept poetry translations into Nynorsk is that poetry translations are considered original works by the Arts Council Norway, and they are funded through the purchasing scheme for new Norwegian literature, rather than through the scheme for translated literature. There is one important difference between the two schemes: whereas the scheme for translated literature has a fixed budget and supports a limited number of titles each year, the scheme for new Norwegian literature is a so-called "automatic" scheme, based uniquely on quality criteria". This scheme funds more titles, and it is generally much easier for the publisher to predict if a particular title will be included in the purchasing scheme for new Norwegian literature than in the scheme for translated literature. A translation of a work by a recognized poet done by a recognized translator will most likely receive funding, which makes it easier for the publishing houses to commission these types of translations (even though most poetry translations will have minimal sales in the general market).

Bakke's two poetry translations, the collection of poems by Dulce María Loynaz in 1999 and by Ángel Escobar and Virgilio Piñera in 2001, were both purchased through the scheme for new Norwegian literature ${ }^{8}$. Piñera's short story collection Kaldt fortalt (Samlaget, 2004) was funded through the scheme for translated literature (Årsmelding 2003 47). Bakke reports that she worked

7 Publishers apply for funding, deliver the given number of copies of the title in question, and usually get their payment from the Arts Council prior to the work of the evaluation committee. If the evaluation committee do not consider the title to be of sufficient quality, the publisher should return the payment (but the Arts Council keeps the books).

8 Information on the title by Dulce María Loynaz in Årsmelding 1999 48. Note: Listed with the title Ei øy på ei øy. Information on the title by Escobar and Piñera in Fossanger, Hilde Fjærtoft. “SV: Opplysninger til forskningsprosjekt.” Received by Idun Heir Senstad, 23 Nov. 2018. 
extensively with various Norwegian publishers to carry out Norwegian translations of more Cuban prose, such as novels by the contemporary writers Ena Lucía Portela, Wendy Guerra, and Leonardo Padura. According to Bakke, the fact that she translates into Nynorsk meant that these initiatives were unsuccessful ${ }^{9}$.

\section{Näumann's translations of Guerra and Padura}

Kari Näumann (b. 1928) ended up translating novels by two of the writers that Bakke initially worked towards translating, namely Wendy Guerra and Leonardo Padura. Like Bakke, Näumann is a member of The Norwegian Association of Literary Translators. Her translator career started relatively late in life, as she started learning Spanish in her fifties ${ }^{10}$. Näumann's first translation came in 1993, an anthology of Spanish Golden Age poetry. Later she published acclaimed translations of Spanish classics such as Tirso de Molina, Pedro Calderón de la Barca, Lope de Vega, and Federico García Lorca. The first Cuban title, Guerra's Todos se van (Bruguera, 2006), was published in Norwegian (Bokmål) as Alle drar sin vei in 2011 through Bokvennen, a small independent publisher. Näumann travelled to Cuba on various occasions; her first trip was in 2002. She often encountered Tove Bakke in Havana, Näumann reports. During one of their stays in Cuba, the two translators went to visit a Norwegian literary scholar who lived in Havana at the time, Hans Jacob Ohldieck (who now holds a PhD with a thesis on José Lezama Lima and another classic author of Cuban literature, Severo Sarduy). Näumann recalls that she spotted Guerra's novel at Ohldieck's home. He warmly recommended the novel, and since Näumann was looking for a new translation project, she suggested the book to Bokvennen, the Norwegian publisher with which she had worked the most. "I believe that more or less everything that I have translated, I have suggested myself to the publisher," Näumann explained in the interview. Later she suggested Nunca fui primera dama (Bruguera, 2008), which was published in Näumann's translation in 2012. The Arts Council Norway supported both these novels through the purchasing

\footnotetext{
9 Parallel to building her translation career, Bakke worked part-time in administration at the Arts Council Norway (1995-2008). This means that she was particularly well informed about the possibilities for translation funding through the purchasing scheme. She would, however, not handle funding applications that she was involved in herself.

10 Unless otherwise stated, the source of information in this section is Näumann, Kari. Personal interview. 16 June 2015.
} 
scheme for translated literature ${ }^{11}$. Näumann also considered Guerra's subsequent novel, entitled Negra (Anagrama, 2014), but concluded that this novel would be too complicated to translate because of the centrality of the Spanish word "negra" (black, referring to race) in the narrative ${ }^{12}$.

After finishing the Guerra novels, Näumann again turned to Hans Jacob Ohldieck for advice on possible Cuban titles to translate. He suggested various writers, and Näumann chose to proceed with Leonardo Padura, probably the best-known contemporary Cuban writer today. Padura's most famous works are the four crime novels in the so-called "Havana Quartet," originally published in the 1990s in Cuba and later picked up by the Spanish publisher Tusquets, which published Máscaras, originally the third book in the series, in 1997. A miniseries based on the novels premiered on Netflix in 2016. Näumann translated all four novels for Bokvennen ${ }^{13}$. The novels did not receive the expected funding through the purchasing scheme for translated literature. This postponed the publication dates for the books.

What emerges from the above accounts is a multiple mediatorship that made the Norwegian translations of Wendy Guerra and Leonardo Padura possible. Näumann suggested the writers and their novels to the publisher; these suggestions, coming from an experienced and trusted translator with whom they had previously worked, were accepted. Both Bakke and Ohldieck are, however, co-mediators of these novels. In Norwegian translation circles, Bakke is known for her long-running engagement with Cuba and Cuban literature, and Näumann and/or the publisher most likely knew about Bakke's prior attempts to suggest Guerra and Padura to Norwegian publishers. Ohldieck, in addition to suggesting the writers to Näumann, is also the author of an epilogue printed in Alle drar sin vei (Ohldieck), in the form of a personal essay constructed around Ohldieck's own email correspondence with Wendy Guerra. In the essay, Ohldieck analyses Guerra's authorship and draws lines to central, but often marginalized, Cuban writers, such as Leonardo Padura, Dulce María Loynaz and José Lezama Lima, and the contemporary Pedro Juan Gutiérrez.

11 Both translations' colophon pages state "Innkjøpt av Norsk Kulturråd” (Purchased by Arts Council Norway).

12 A fourth Guerra novel, Revolusjonssøndag (orig. Domingo de Revolución, Anagrama, 2016), was published by Bokvennen in Näumann's translation in 2017.

13 Only two of the translations, Vinter i Havana (2012) and Storm i Havana (2014) appear in the material of the present investigation. The translation of the third novel in the series, Maskespill i Havana, came in 2015 (orig. Máscaras, Tusquets 1997). The fourth and last translation, of Paisaje de otoño (Tusquets 1998), had not yet been published at the time this article was written. 


\section{The multiple mediatorship behind Gutiérrez's Trilogía sucia de La Habana}

The Norwegian translation of Gutiérrez's Trilogía sucia de La Habana (Anagrama, 1998) was published in 2005, by the large, traditional publishing house Gyldendal. The translator, Hege Hammer, described the novel as "the apple of her eye"-the one translation that she initiated herself and that also brought her many new experiences $^{14}$. In 2005, Hammer had translated 12 fictional works from Spanish and English, and she was a member of the Norwegian Association of Literary Translators. Her first reading of Gutiérrez's work occurred because her mother gave her one of his books as a gift. Soon after, she talked to the publishing house, which agreed to commission two reader's reports-one for Trilogía sucia de La Habana, and another for a second Gutiérrez novel, El rey de La Habana. Hammer wrote the reports, and recommended Trilogía. The translation eventually came out in 2005; Hammer had, however, already signed the contract with the publisher in 2002, at a time when there were still few translations of Trilogía available. Hammer explained that prior to the agreement with the publisher, she had travelled to Cuba together with Tove Bakke and the Norwegian writer Ragnar Hovland to attend the Havana book fair. Bente Lodgaard-a manuscript editor at Gyldendal at the time, who was later the corresponding editor for Hammer's translationalso attended the book fair. Lodgaard has extensive knowledge of the Spanish language and the Hispanic world, and she is now a translator from Spanish and English and a member of the Norwegian Association of Literary Translators. Another editor who worked at Gyldendal at the time recalls that various persons from the "Spanish translation environment" were particularly enthusiastic about the novel, and that "they" advocated for this novel over a period of time ${ }^{15}$. In sum, all this clearly testifies to a multiple mediatorship in which the translator played a central role and which involved other actors and partial overlaps with the multiple mediatorship described for the Guerra and Padura translations.

\section{Discussion of the independent cultural mediators' agency}

The independent cultural mediators that worked with Cuban literature between 1990 and 2014 were all agents with considerable symbolic capital in the

14 Unless otherwise stated, the source of information in this section is Hammer, Hege. Personal interview. 18 June 2015.

15 Anonymous. Personal interview. 23 March 2017. 
Norwegian literary field. All the translators were widely experienced and had been recognized for their work through important Norwegian literary prizes (Risvik, Bakke) or by membership in the Norwegian Association of Literary Translators (Bakke, Näumann, Hammer). Apart from the translators-who in the cases of Bakke, Näumann and Hammer assumed mediating roles far beyond the textual translation activity-the other two most central cultural mediators were Kjell Olaf Jensen and Hans Jacob Ohldieck. Both had favorable positions in the field: Jensen was a well-known literary critic and translator from French and German, and Ohldieck was an academic who specialized in Cuban literature. Even agents who had a minor (or even coincidental) role in the selection of these works-such as the academic who happened to bring back Dulce María Loynaz' poetry from a vacation in Cuba, or the Spanish-speaking manuscript editor who was part of the multiple mediatorship behind Pedro Juan Gutiérrez' book-held some level of symbolic capital in the Norwegian literary field.

Most agents in the multiple mediatorships operating in the selection processes pertaining to the different Cuban works were Spanish-language specialists and experts (or aspiring experts) on Cuban literature or culture. Most of them travelled repeatedly to Cuba, and two of the translators (Bakke and Näumann) reported having discovered the writers that they finally translated on trips to Cuba. The case of Guerra's Todos se van, which caught Näumann's attention while visiting Hans Jacob Ohldieck in Havana, is particularly intriguing. Even though Guerra lives and writes in Cuba, the majority of her work has not been published there. Todos se van was published in Spain by Bruguera in 2006, and it is not generally available in Cuban bookstores, since the state is the only actor authorized to publish and sell new books. Ohldieck must have brought the book to Cuba, a fact that adds an extra layer to the analysis and certainly problematizes the idea that literature can travel directly between peripheries.

That said, an important result of this analysis is that the nine Cuban works selected by independent cultural mediators are either canonized classics of 20th century Cuban literature (Lezama Lima, Loynaz, Piñera, and Escobar), or internationally recognized works by contemporary Cuban writers based in Cuba (Guerra, Padura, and Gutiérrez). Cuban-American writers (writing in English) or other Cuban writers that permanently reside outside of Cuba (often writing in Spanish) dominated the selection of Cuban works in Norway throughout the years 1990-2014, however none of these diaspora works were selected or otherwise advocated for by independent cultural mediators. Instead, the selection of these works was embedded in central structures of the international translation market (Senstad, "Norwegian Publishers' Views"). This example of Cuban literature in Norway demonstrate how the dominant mechanisms that govern the international literary trade favor central literatures over peripheral ones: the diaspora 
writers' geographical and cultural proximity to centers of the international publishing industry clearly facilitated their wider circulation. In light of this, the activities of the independent cultural mediators that are the focus of the present article gain an ethical dimension; their agency emerges as essential for the inclusion of non-diaspora Cuban writers within Norwegian translated literature.

Six of the nine translations were funded by the Arts Council Norway through the purchasing scheme for literature. This funding economically benefits both the involved publisher and the translator, and thus directly supported the work of the independent cultural mediators in this study. The funding is explicitly aimed at supporting literary diversity, and it is clear that this strong state funding program provided favorable conditions for the translation of Cuban literature throughout the studied period (1990-2014).

\section{Agency in context-consecration mechanisms at play}

The Norwegian translation and publication of the nine works in question were the result of independent cultural mediators' personal initiative and interest, and individual tastes and preferences played important roles. However, such con amore projects are also embedded within the power relations of the international literary field. All the writers and the works enjoyed some level of regional and international consecration prior to the Norwegian translation-publication by Spanish publishing houses, literary prizes, translations, academic scholarship, etc. Even if the cultural mediators themselves did not always recognize this as a direct influence on their choices, a closer look at the circulation patterns of the writers and works demonstrate that Hispanic and Anglo-American consecration was a precondition of the translation of classic and contemporary Cuban literature into Norwegian (see Table 2).

Table 2 shows that editions of all the translated works-possibly with the exception of Escobar's work, and Piñera's Cuentos frios-had been published in Spain prior to the Norwegian translations. In itself, this is indicative of consecration in the Hispanic world, since Spanish publishers market their books in Spain and elsewhere in the Spanish-speaking world (but not in Cuba). Several of the writers had also received important Spanish-language literary prizes.

English translations of most of the works were also available prior to the Norwegian translations. The exceptions are Dulce Maria Loynaz and Virgilio Piñera, for whom important English translations were published after the Norwegian translation. Another exception is Wendy Guerra; the Norwegian translation of Todos se van was published in 2011, and the English translation 
Table 2: Cuban Writers in Norwegian Translation (1990-2014): Examples of Consecration in the Hispanic and Anglo-American Fields.

\begin{tabular}{|c|c|c|c|}
\hline $\begin{array}{l}\text { Year of } \\
\text { Norwegian } \\
\text { translation }\end{array}$ & Author & $\begin{array}{l}\text { Consecration examples: } \\
\text { Hispanic world }\end{array}$ & $\begin{array}{l}\text { Consecration examples: } \\
\text { Anglo-American }\end{array}$ \\
\hline 1999 & $\begin{array}{l}\text { Dulce María } \\
\text { Loynaz }\end{array}$ & $\begin{array}{l}\text { Most of her poetry collections } \\
\text { were published in Spain in the } \\
1940 \text { s and 1950s (Behar): } \\
\text { Juegos de agua. Madrid, Editora } \\
\text { Nacional, } 1947 . \\
\text { Poemas sin nombre, Madrid, } \\
\text { Aguilar, } 1953 . \\
\text { Premio Cervantes, } 1992 .\end{array}$ & $\begin{array}{l}\text { The poet caught the attention of } \\
\text { the Norwegian translator Tove } \\
\text { Bakke through a bilingual edition } \\
\text { (English-Spanish), probably: } \\
\text { Poems Without Name. Trans. } \\
\text { Harriet de Onís, Havana, Editorial } \\
\text { José Martí, } 1993 \text { (translated in } \\
\text { 1958). } \\
\text { Later poetry collections include } \\
\text { Dulce María Loynaz: A Woman in } \\
\text { Her Garden. Trans. Judith } \\
\text { Kerman, Buffalo, NY, White Pine } \\
\text { Press, } 2002 \text {. } \\
\text { Absolute Solitude. Trans. James } \\
\text { O’Connor, Brooklyn, NY, } \\
\text { Archipelago books, } 2016 .\end{array}$ \\
\hline $\begin{array}{l}2001 \\
2004\end{array}$ & $\begin{array}{l}\text { Virgilio } \\
\text { Piñera and } \\
\text { Ángel } \\
\text { Escobar } \\
\text { Virgilio } \\
\text { Piñera }\end{array}$ & $\begin{array}{l}\text { Virgilio Piñera. La isla en peso. } \\
\text { Barcelona, Tusquets, } 2000 . \\
\text { Cuentos fríos. Buenos Aires, } \\
\text { Losada, } 1956 .\end{array}$ & $\begin{array}{l}\text { Sporadic translations of single } \\
\text { poems. } \\
\text { The Weight of the Island: } \\
\text { Selected Poems of Virgilio } \\
\text { Piñera. Trans. Pablo Medina, } \\
\text { Diálogos, } 2014 . \\
\text { Cold Tales. Trans. Mark Schafer, } \\
\text { Hygiene, Colorado, Eridanos } \\
\text { Press, } 1988 .\end{array}$ \\
\hline 2002 & $\begin{array}{l}\text { José } \\
\text { Lezama } \\
\text { Lima }\end{array}$ & $\begin{array}{l}\text { Paradiso. Mexico, Ediciones } \\
\text { Era, } 1968 . \\
\text { Paradiso. Madrid, Ediciones } \\
\text { Cátedra, } 1980 .\end{array}$ & $\begin{array}{l}\text { Paradiso. } 1974 . \text { Trans. Gregory } \\
\text { Rabassa, New York, Farrar, } \\
\text { Strauss \& Giroux, } 2000 .\end{array}$ \\
\hline 2005 & $\begin{array}{l}\text { Pedro Juan } \\
\text { Gutiérrez }\end{array}$ & $\begin{array}{l}\text { Trilogía sucia de La Habana. } \\
\text { Barcelona, Anagrama, } 1998 . \\
\text { Subsequent books published by } \\
\text { Anagrama. } \\
\text { Premio Alfonso García-Ramos } \\
\text { de Novela, } 2000 . \\
\text { Premio Narrativa Sur del } \\
\text { Mundo, } 2003 .\end{array}$ & $\begin{array}{l}\text { Dirty Havana Trilogy. Trans. } \\
\text { Natasha Wimmer. London, Faber } \\
\text { and Faber, } 2001 .\end{array}$ \\
\hline
\end{tabular}


Table 2 (continued)

\begin{tabular}{|c|c|c|c|}
\hline $\begin{array}{l}\text { Year of } \\
\text { Norwegian } \\
\text { translation }\end{array}$ & Author & $\begin{array}{l}\text { Consecration examples: } \\
\text { Hispanic world }\end{array}$ & $\begin{array}{l}\text { Consecration examples: } \\
\text { Anglo-American }\end{array}$ \\
\hline $\begin{array}{l}2011 \\
2012\end{array}$ & $\begin{array}{l}\text { Wendy } \\
\text { Guerra }\end{array}$ & $\begin{array}{l}\text { Todos se van. Barcelona, } \\
\text { Bruguera, } 2006 . \\
\text { Nunca fui primera dama. } \\
\text { Barcelona, Bruguera, } 2008 . \\
\text { Subsequent books published by } \\
\text { Anagrama (Barcelona) and } \\
\text { Alfaguara (Barcelona). } \\
\text { Premio Bruguera (2006). }\end{array}$ & $\begin{array}{l}\text { Everyone leaves. Trans. Achy } \\
\text { Obejas, AmazonCrossing, } 2012 .\end{array}$ \\
\hline $\begin{array}{l}2012 \\
2014\end{array}$ & $\begin{array}{l}\text { Leonardo } \\
\text { Padura }\end{array}$ & $\begin{array}{l}\text { Máscaras. Barcelona, Tusquets, } \\
1997 . \\
\text { Subsequent books published by } \\
\text { Tusquets. } \\
\text { Several prizes, for example } \\
\text { Premio Hammett, } 2006 . \\
\text { Premio Princesa de Asturias de } \\
\text { las Letras, } 2015 \text {. }\end{array}$ & $\begin{array}{l}\text { Havana Blue. Trans. Peter Bush, } \\
\text { London, Bitter Lemon Press, } \\
2007 . \\
\text { Havana Gold. Trans. Peter Bush, } \\
\text { London, Bitter Lemon Press, } \\
2008 .\end{array}$ \\
\hline
\end{tabular}

was published in 2012. The second novel, Nunca fui primera dama, has not yet been translated into English.

Despite these exceptions, the data presented in the table largely confirm the double consecration hypothesis (Lindqvist, "Bibliomigrationsmönster," "Dubbel konsekration"): the writers and works enjoyed some level of consecration both in the Hispanic and Anglo-American fields prior to the Norwegian translations. It is complicated to evaluate the extent to which this directly influenced the independent cultural mediators' work. However, it is interesting to note that none of the interviewed translators reported that the English translation was a factor in their selection processes. At least two of the mediators were directly inspired by prior translations into languages other than English: an Austrian poetry collection inspired Bakke's translations of Piñera and Escobar's poetry, and the French translation of Paradiso caused Jensen's interest in Lezama Lima. Such instances demonstrate how micro-perspectives serve to lend nuance to macro-perspectives on how literature travels, and they highlight the complexities of literary circulation.

The arguments presented in this article largely dispute the idea of Swedish consecration as a necessary precondition for Norwegian translations of Spanish Caribbean literature, and thus they contradict the claim regarding the centrality 
of Swedish made by Lindqvist ("The Scandinavian”). To test Lindqvist's hypothesis of Sweden as a center for Scandinavian literary translation, I performed searches in the online database världslitteratur.se (Sweden's most complete thematic overview of literary translations from Africa, Asia and Latin America) ${ }^{16}$ and in the National Library of Sweden's online database (www.libris.kb.se) (conducted 1 November 2018). The results are presented below (Table 3).

Table 3: Cuban Writers in Norwegian Translation (1990-2014): Status in Sweden.

\begin{tabular}{|c|c|c|c|}
\hline Author & $\begin{array}{l}\text { Norwegian } \\
\text { title(s), } \\
\text { Year of } \\
\text { translation(s) }\end{array}$ & www.varldslitteratur.se & $\begin{array}{l}\text { National Library of } \\
\text { Sweden } \\
\text { (www.libris.kb.se): } \\
\text { Books in Sweden by } \\
\text { the writer }\end{array}$ \\
\hline $\begin{array}{l}\text { Dulce María } \\
\text { Loynaz }\end{array}$ & Svart vin, 1999 & $\begin{array}{l}\text { Entry on Dulce María Loynaz, } \\
\text { but no translations. }\end{array}$ & None \\
\hline $\begin{array}{l}\text { Virgilio Piñera } \\
\text { and Ángel } \\
\text { Escobar } \\
\text { Virgilio Piñera }\end{array}$ & $\begin{array}{l}\text { To cubanske, } 2001 \\
\text { Kaldt fortalt, } 2004\end{array}$ & $\begin{array}{l}\text { No entries on Piñera and } \\
\text { Escobar in varldslitteratur.se }\end{array}$ & $\begin{array}{l}\text { None } \\
\text { None }\end{array}$ \\
\hline José Lezama Lima & Paradiso, 2002 & $\begin{array}{l}\text { Entry on Lezama Lima, but no } \\
\text { translations. }\end{array}$ & $\begin{array}{l}\text { Poems included in an } \\
\text { anthology: } \\
\text { Kubas poeter } \\
\text { drömmer inte mer, } \\
1969\end{array}$ \\
\hline $\begin{array}{l}\text { Pedro Juan } \\
\text { Gutiérrez }\end{array}$ & $\begin{array}{l}\text { Den skitne } \\
\text { Havanna-trilogien, } \\
2005\end{array}$ & $\begin{array}{l}\text { Entry on Gutiérrez. One } \\
\text { translation. } \\
\text { Dirty Havanna-Havanna- } \\
\text { trilogin, } 2010\end{array}$ & $\begin{array}{l}\text { Dirty Havanna- } \\
\text { Havanna-trilogin, } \\
2010\end{array}$ \\
\hline Wendy Guerra & $\begin{array}{l}\text { Alle drar sin vei, } \\
2011 \\
\text { Jeg var aldri } \\
\text { førstedame, } 2012\end{array}$ & $\begin{array}{l}\text { Entry on Wendy Guerra. One } \\
\text { book translation. } \\
\text { Alla ger sig av, } 2012\end{array}$ & Alla ger sig av, 2012 \\
\hline Leonardo Padura & $\begin{array}{l}\text { Vinter i Havana, } \\
2012 \\
\text { Storm i Havana, } \\
2014\end{array}$ & $\begin{array}{l}\text { No entry on Padura in } \\
\text { varldslitteratur.se }\end{array}$ & None \\
\hline
\end{tabular}

16 Lindqvist ("Bibliomigrationsmönster") uses the same database to confirm the double consecration hypothesis for Spanish Caribbean-mostly Cuban-literature translated into Swedish between 1990 and 2015. This study does not explore Sweden as a Scandinavian center. 
Table 3 demonstrates that none of the nine works were published in Swedish at the time of publication of the Norwegian translation. Two works were later published in Swedish, Gutiérrez' Trilogía sucia de La Habana and Guerra's Todos se van. There are entries on Dulce María Loynaz and Lezama Lima in världslitteratur.se, but no listed translations. Piñera, Escobar and Padura do not have entries in the database. The National Library's catalogue confirms that there are no Swedish translations of any works by these writers, except the inclusion of poems by Lezama Lima in an anthology from 1969.

\section{Concluding remarks}

An important finding of this study is that the studied independent cultural mediators advocated for canonized $20^{\text {th }}$-century Cuban literature or works by contemporary Cuban writers based in Cuba, originally written in Spanish. In doing so, they significantly contributed to a diverse representation of Cuban literature in Norway, since the Cuban fictional works that entered Norway through the publishers' established networks were written mostly in English by Cuban diaspora writers.

The independent mediators enacted their agency in and through alternative networks, which kept their distance from the central networks of publishing professionals (such as literary scouts and literary agents) and the workings of the international translation market. In a sense, they were smugglers (RoigSanz and Meylaerts) who created their own information sources and selection principles. These mediators of the Cuban works were motivated and driven by a personal interest in Spanish and/or Cuban literature, and in the case of the translators, a personal interest combined with the prospect of work. The Arts Council Norway provided funding for six of the nine translations, which makes it an important facilitator of Norwegian translations of Cuban literature throughout the studied period.

The survey of the nine works' regional and international consecration clearly demonstrated how close attention to particular bodies of works can lend nuance to macro-perspectives on literary circulation. The independent cultural mediators' choices were most likely influenced by Hispanic and Anglo-American consecration of the writers and works, but the link is not always very clear, and translations into other languages also inspired some of the agents. The survey furthermore questions the idea of Sweden as a consecrating center for translation in Scandinavia, since none of the nine works were published in Swedish prior to the Norwegian translation. 
In more general terms, the results of the present study highlight how the agency of independent cultural mediators may be vital to promoting literary voices from the Global South. Many peripheral literatures fall beneath the radar of the international translation market's central mechanisms, and the work of invested cultural mediators can provide an alternative means of selection for translation. The absence of a coherent strategy for international literary promotion and state funding from the source culture is, for example, not unique to Cuba-other peripheral literatures from the Global South face similar problems. Uneven power structures between countries and cultures favor some literatures over others in the international marketplace, and in this landscape, cultural mediators such as the ones studied in the present article can assume key roles as promoters of literary diversity.

\section{Works Cited}

Alvstad, Cecilia et al. (eds.). Textual and Contextual Voices of Translation. John Benjamins, 2017.

Bakke, Tove. “Etterord.” Svart vin. Dulce María Loynaz. Trans. Tove Bakke. Cappelen, 1999, pp. 83-91.

--.. "Etterord." To cubanske. Virgilio Piñera og Ángel Escobar i utval. Virgilio Piñera and Ángel Escobar. Trans. Tove Bakke. Samlaget, 2001, pp. 140-163.

Behar, Ruth. "Dulce Maria Loynaz: A Woman Who No Longer Exists.” Michigan Quarterly Review, vol. 36, no. 4, 1997, http://hdl.handle.net/2027/spo.act2080.0036.401, last visit 10/01/19.

Bourdieu, Pierre. "A Conservative Revolution in Publishing." Translation Studies, vol. 1, no. 2, 2008, pp. 123-153.

Bourdieu, Pierre. The Rules of Art: Genesis and Structure of the Literary Field. Trans. Susan Emanuel, Polity Press, 1996.

Bourdieu, Pierre. The Field of Cultural Production: Essays on Art and Literature. Ed. Randal Johnson. Polity Press, 1993.

Buendia, Carmen Toledano. "Listening to the Voice of the Translator: A Description of Translator's Notes as Paratextual Elements.” Translation \& Interpreting, vol. 5, no. 2, 2013, pp. 149-162.

“Cappelen Damms historie." Cappelen Damm. www.cappelendamm.no/cappelendamm/omforlaget/article.action?contentld=39309, last visit 25/11/18.

Casanova, Pascale. "Literature as a World." New Left Review, no. 31, 2005, pp. 71-90.

--.. The World Republic of Letters. Trans. M.B. DeBevoise. Harvard University Press, 2004.

Dimitriu, Rodica. “Translators' Prefaces as Documentary Sources for Translation Studies." Perspectives, vol. 17, no. 3, 2009, pp. 193-206.

Franssen, Thomas and Giselinde Kuipers. "Coping with Uncertainty, Abundance and Strife: Decision-Making Processes of Dutch Acquisition Editors in the Global Market for Translations." Poetics, vol. 41, no. 1, 2013, pp. 48-74.

Gutiérrez, Pedro Juan. Diálogo con mi sombra. Ediciones Unión, 2015. 
--. Todo sobre Pedro Juan. www.pedrojuangutierrez.com, last visit 20/10/18.

Hacohen, Ran. "Literary Transfer between Peripheral Languages: A Production of Culture Perspective.” Meta, vol. 59, no. 2, 2014, pp. 297-309.

Heilbron, Johan. "Towards a Sociology of Translation: Book Translations as a Cultural WorldSystem." European Journal of Social Theory, vol. 2, no. 4, 1999, pp. 429-444.

Heilbron, Johan and Gisèle Sapiro. "Politics of Translation: How States Shape Cultural Transfers." Literary Translation and Cultural Mediators in 'Peripheral' Cultures. Eds. Diana Roig-Sanz and Reine Meylaerts. Palgrave Macmillan, 2018, pp. 183-208.

Izquierdo, José María. LETRAS. University of Oslo, Oct. 2018. ub-fmserver.uio.no/letras/home. php, last visit 18/10/18.

Jansen, Hanne and Anna Wegener (eds.). Authorial and Editorial Voices in Translation, vol. 1. Éditions québécoises de l'œuvre, 2013.

Jensen, Kjell Olaf. “Etterord.” Paradiso. José Lezama Lima. Trans. Kjell Risvik. Pax, 2002, pp. 555-559.

Kinnunen, Tuija and Kaisa Koskinen, editors. Translators' Agency. Tampere University Press, 2010.

Kulturstatistikk 2000. Statistics Norway, Jan. 2002.

Kulturstatistikk 2016. Statistics Norway, 13 Dec. 2017.

Kumaraswami, Par and Antoni Kapcia. Literary Culture in Cuba: Revolution, Nation-Building and the Book. Manchester University Press, 2012.

Lauritsen, Vibeke. “Tove Bakke.” Allkunne - levande leksikon, 11 Apr. 2018. www.allkunne.no/ framside/biografiar/b/tove-bakke/85/1543/, last visit 10/09/18.

Lindqvist, Yvonne. "Bibliomigrationsmönster från periferi till semiperiferi: Om den samtida spanskkaribiska litteraturen i svensk översättning." Tidskrift för litteraturvetenskap, vol. 1, no. 2, 2018, pp. 90-104.

--.. "Dubbel konsekration-en förutsättning för svensk översättning av utomeuropeisk litteratur? Maryse Condé som exempel." Språk \& stil, vol. 21, 2011, pp. 140-170.

---. "The Scandinavian Literary Translation Field from a Global Point of View. A Peripheral (Sub)Field?" Institutions of World Literature: Writing, Translation, Markets. Eds. Stefan Helgesson and Pieter Vermeulen. Routledge, 2018, pp. 174-187.

Lomheim, Sylfest. "Kjell Risvik." Store norske leksikon, 17 Mar. 2009. www.snl.no/ Kjell_Risvik, last visit 25/09/18.

“Med andre ord." Universitas, 25 Apr. 2001. www.universitas.no/kultur/659/med-andre-ord/, last visit 25/09/18.

Ohldieck, Hans Jacob. “Det hvite arket. Om Wendy Guerra i Havanna.” Alle drar sin vei. Wendy Guerra. Trans. Kari Näumann. Bokvennen, 2011, pp. 269-280.

Roig-Sanz, Diana and Reine Meylaerts. "General Introduction. Literary Translation and Cultural Mediators. Toward an Agent and Process-Oriented Approach." Literary Translation and Cultural Mediators in 'Peripheral' Cultures. Customs Officers or Smugglers? Eds. Diana Roig-Sanz and Reine Meylaerts. Palgrave Macmillan, 2018, pp. 1-37.

Schwartz, Cecilia. "From Nuoro to Nobel: The Impact of Multiple Mediatorship on Grazia Deledda's Movement within the Literary Semi-Periphery." Perspectives, vol. 26, no. 4, 2018, pp. 526-542.

Senstad, Idun Heir. "Bokomslag som formidling. Cubanske romaner i norsk innpakning." Litteratur- og kulturformidling. Nye analyser og perspektiver. Eds. Helge Ridderstrøm and Tonje Vold. Pax, 2015, pp. 166-188. 
-.-. "The Making of a Bestseller-in-Translation. Cecilia Samartin as the Voice of Cuba." Textual and Contextual Voices of Translation. Eds. Cecilia Alvstad et al. John Benjamins, 2017, pp. 61-79.

--.. “Norwegian Publishers' Views on Selecting Peripheral Literature for Translation.” Manuscript in preparation.

Solum, Kristina. "The Tacit Influence of the Copy-Editor in Literary Translation.” Perspectives, vol. 26, no. 4, 2018, pp. 543-559.

-.-. "Translators, Editors, Publishers, and Critics. Multiple Translatorship in the Public Sphere." Textual and Contextual Voices of Translation. Eds. Cecilia Alvstad et al. John Benjamins, 2017, pp. 39-60.

Tahir-Gürcaglar, Sehnaz. "Agency in Allographic Prefaces in Translated Works: An Initial Exploration of the Turkish Context." Authorial and Editorial Voices in Translation 2. Editorial and Publishing Practices. Eds. Hanne Jansen and Anna Wegener. Éditions québécoises de l'œuvre, 2013.

van Es, Nicky and Johan Heilbron. "Fiction from the Periphery: How Dutch Writers Enter the Field of English-Language Literature.” Cultural Sociology, vol. 9, no. 3, 2015, pp. 296-319.

Vikør, Lars, S, and Ernst Håkon Jahr. "Språk i Norge.” Store norske leksikon, 12 Nov. 2018. www.snl.no/språk_i_Norge, last visit 25/09/18.

Whitfield, Esther. Cuban Currency: The Dollar and "Special Period" Fiction. University of Minnesota Press, 2008.

Årsmelding 1999. Arts Council Norway, 1999.

Årsmelding 2003. Arts Council Norway, 2003.

Årsmelding 2013. Arts Council Norway, 2013.

Årsmelding 2014. Arts Council Norway, 2014. 